\title{
ALUR TRANSMISSION OF RELIGIOUS KNOWLEDGE AND ISLAMIC THOUGHT DALAM ISLAMIC THOUGHT; AN INTRODUCTION KARYA ABDULLAH SAEED TERBITAN ROUTLEDGE 2006
}

\author{
Ahmad Putra \\ UIN Sunan Kalijaga, putrakonseris96@gmail.com
}

Diterima: 4 Februari 2019

Direvisi : 15 Mei 2019

Diterbitkan: 30 Juni 2019

\begin{abstract}
This paper describes the fundamental teachings of the Prophet Mubammad, the development of religious knowledge, and the social and political context that shaped the intellectual tradition of Islam. Abdullah Saeed, in the transmission of spiritual experience and Islamic thought, introduced the basic teachings of Islam. The emergence of Islam is closely related to the bistory of its birthplace, the city of Mecca. Besides, Abdullah Saeed also discussed the beginning of the development of religious knowledge, which was immediately explained by the Qur'an and the emergence of sects that influenced the course of change towards truth. Each of these sects and sects has its doctrine, and if there is anything against it, there is undoubtedly a separate assessment of the differences that are believed. Several groups with various theological or religio-political orientations emerged. Among them are Kharijis (khawarij), Shia, Qadaris (qadariyya), Mu'tarilis (mu'tazila), Jabris (jabriyya) and Muriz'is (muriz'a).
\end{abstract}

Keywords: Muhammad's Fundamental Teachings, Development of Knowledge of Religion, Social, and Political Context.

\begin{abstract}
Abstrak
Tulisan ini menggambarkan ajaran-ajaran fundamental Nabi Mubammad, pengembangan pengetabuan agama dan konteks sosial dan politik yang membentuk tradisi intelektual yang dalam perkara ini Abdullah Saeed dalam Transmisi pengetahuan agama dan pemikiran Islam mengenalkan tentang ajaranajaran dasar agama Islam. Munculnya agama Islam sangat erat kaitannya dengan sejarah tempat kelabirannya yaitu kota Mekkah. Di samping itu, Abdullah Saeed juga membicarakan awal munculnya pengetabuan agama yang langsung dijelaskan Alquran serta munculnya sekte-sekte yang mempengarubi jalannya perubahan menuju kebenaran. Masing-masing sekte dan aliran tersebut memiliki masing-masing doktrin dan apabila ada yang bertentangan antara satu dengan yang lain, maka pastinya ada penilaian tersendiri dari perbedaan yang diyakini. Beberapa golongan dengan beragam orientasi teologis atau religiopolitik muncul. Diantaranya adalah Kharijis (khawarij), Syiah, Qadaris (qadariyya), Mu'tazilis (mu'tazila), Jabris (jabriyya) dan Murji'is (murji'a).
\end{abstract}

Kata Kunci: Ajaran Fundamental Nabi Muhammad, Pengembangan Pengetahuan Agama, Konteks Sosial dan Politik.

\section{PENDAHULUAN}

Dalam buku "Islamic Though an Introduction" oleh Abdullah Saeed (2006 yang berjudul "Transmission of Religious Knowledge and Islamic Thought" (transmisi pengetahuan agama dan pemikiran Islam) mengenalkan tentang ajaran-ajaran dasar agama Islam. Munculnya agama Islam sangat erat kaitannya dengan sejarah tempat kelahirannya yaitu kota Mekkah. Pada awal abad ke tujuh dari Common Era (CE) Kota Mekkah awalnya adalah kota yang agak marginal atau terpinggirkan dari pengaruh dua kekaisaran yang kuat pada waktu itu, yaitu kekaisaran Bizantium yang sebagian besar Kristen dan Kekaisaran Sassaniyah yang sebagian besar Zoroastrian, keduanya terletak di Utara Arab.

Sebagian besar penduduk Kota Mekkah yaitu suku Quraisy, karena tidak ada penguasa atau struktur formal pemerintahan, maka Kota Mekkah diperintah melalui proses konsultatif yang dikelola oleh penatua dan ketua. Dari segi ekonomi, Kota Mekkah dilalui oleh jalur perdagangan yang ramai 
menghubungkan Yaman di Selatan dan Syria di Utara, sehingga penduduk Kota Mekkah mengandalkan perdagangan barang menggunakan transportasi unta (kafilah) sebagai mata pencaharian mereka. Dari segi pendidikan pun terbatas pada keterampilan dasar bertahan hidup, seperti penggunaan persenjataan (pedang dan panah), menunggang unta dan kuda.

Hanya beberapa orang melek huruf, akan tetapi dengan keterbatasan pendidikan tersebut tidak menghalangi penduduk Kota Mekkah untuk mencintai bahasa mereka, yaitu bahasa Arab. ${ }^{1}$

Di Kota Mekkah, puisi dan penyair sangat dihormati, dan ekspresi dalam bahasa yang indah dianggap sebagai puncak intelektual. Menurut catatan tradisional, beberapa puisi yang terkenal dipajang di tempat-empat penting seperti Ka`bah, yaitu sebuah bangunan berbentuk kubus yang berfungsi sebagai titik ziarah utama bagi orang-orang Arab pra-Islam dan bagi umat Islam sampai saat ini.

Nabi Muhammad lahir di Kota Mekkah sekitar tahun 570 Masehi. Beliau merupakan keturunan keluarga bangsawan Arab, yaitu Bani Hasyim dan suku Quraisy, Ayahnya Abdullah yang merupakan anak bungsu dari Abdul Muthalib meninggal sebelum Nabi Muhammad lahir dan ibunya Siti Fatimah meninggal saat Nabi Muhammad masih kanak-kanak, lalu Nabi Muhammad diasuh oleh kakeknya yang tidak lama kemudian meninggal, lalu kemudian Nabi Muhammad diasuh oleh pamannya yaitu Abu Thalib.

Pada usia dua puluh tahun Nabi Muhammad menikah dengan Siti Khadijah. Pada usia yang ke empat puluh tahun Nabi Muhammad menerima wahyu yang pertama

\footnotetext{
1 Abdullah Saeed, Islamic Thought An Introduction, (New York : Routledge, 2006), 2
}

yaitu Alquran Surat al-Alaq ayat 1-5 pada tahun 610 Masehi di Gua Hira. ${ }^{2}$

Setelah menerima wahyu selanjutnya Nabi Muhammad mulai berdakwah dimulai dari teman dan keluarga dekat, setelah itu wilayah dakwahnya lebih luas lagi. Nabi Muhammad menyampaikan bahwa Tuhan itu hanya ada satu, sang pencipta dan penopang segalanya, yang mengutus Nabi Muhammad sebagai pembawa pesan. Seruan Nabi Muhammad kepada penduduk Mekkah untuk menyembah Allah SWT tidak dapat diterima oleh penduduk Mekkah yang sudah dahulu menyembah berhala yang ditempatkan di Ka 'bah. Namun, sejumlah kerabat dan teman dekat Nabi Muhammad dan beberapa penduduk mengikuti seruan Nabi Muhammad dan menjadi pengikutnya. Inilah usaha dan perjuangan Muhammad dalam menebarkan agama kebaikan bagi banyak orang dan orangorang yang dicintainya. ${ }^{3}$

Dalam waktu yang sama ketika ajaran Islam mulai berkembang di Mekkah, terjadi pertentangan oleh orang-orang yang memiliki kepentingan kuasa di Mekkah yang merasa tertantang oleh ajaran Nabi Muhammad yang terikat dengan monoteisme yaitu menyembah satu Tuhan. Mereka mulai menghalangi jalan dakwah Nabi Muhammad, menghukum pengikut Nabi Muhammad terutama budak dan perempuan. Perlahan-lahan penganiayaan di Mekkah meningkat. Karena hal tersebut Nabi Muhammad menyarankan pengikutnya untuk hijrah ke Abyssinia (Ethiopia modern) mencari perlindungan Negus, penguasa Kristen. Kaum muslim yang saat itu jumlahnya sekitar delapan puluh orang pergi ke Abyssinia secara diam-diam pada 615 Masehi. Di bawah perlindungan Negus, kaum muslim pertama menjalankan ibadahnya dengan bebas. Meskipun para pemimpin Mekkah berupaya keras agar umat Islam kembali ke Mekkah.
${ }^{2}$ Ibid, 2
${ }^{3}$ Ibid, 3 
Akan tetapi, orang Negus tidak mengindahkan permintaan para pemimpin Mekkah, dan memberi ijin kepada kaum muslim untuk hidup dan menjalankan agama baru mereka secara bebas di bawah perlindungannya.

\section{METODE PENELITIAN}

Penelitian ini ialah penelitian kepustakaan (library Research) yaitu penelitian yang dilaksanakan dengan menggunakan literatur (kepustakaan) baik berupa buku, catatan maupun laporan hasil penelitian dari peneliti terdahulu. ${ }^{4}$ Sumber data penelitian ini ialah sumber data primer dan sekunder. Adapun sumber data primernya buku karangan Abdullah Saeed, "Transmission Of Religious Knowledge And Islamic Thought," Dalam: Abdullah Saeed, Islamic Thought; An Introduction, (London And New York: Reutledge, 2006). Sedangkan sumber data sekundernya adalah karya-karya lain yang membahas tentang pemikiran Islam menurut Abdullah Saeed.

\section{BIOGRAFI ABDULLAH SAEED}

Abdullah Saeed, seorang pemikir Islam yang mempunyai concerns terhadap interpretasi Alquran. Sebagai seorang sarjana yang pernah mengenyam pendidikan di negara Timur Tengah (Madinah) dan pendidikan di dunia Barat (Australia), Saeed mencoba untuk menawarkan sebuah pendekatan baru dalam memahami teks Alquran sesuai dengan sociobistorical context of the Qur'an at the time of revelation in the first/seventh century and the contemporary concerns and needs of Muslims today. ${ }^{5}$

Abdullah Saeed adalah seorang professor Studi Arab dan Islam di Universitas Melbourne, Australia. Saat ini dia menjabat sebagai Direktur Pusat Studi Islam

4 M. Iqbal Hasan, Pokok-Pokok Materi Metodologi Penelitian dan Aplikasinya, Jakarta: Ghalia Indonesia, 2002), 11

5 Achmad Zaini, "Model Interpretasi AlQur??N Abdullah Saeed," Islamica: Jurnal Studi Keislaman 6, no. 1 (September 1, 2011): 25-36, https://doi.org/10.15642/islamica.2011.6.1.25-36.
Kontemporer di universitas tersebut. Saeed lahir di Maladewa, dari keturunan suku bangsa Arab Oman yang bermukim di pulau Maladewa. Maldives adalah sebuah negara berbentuk Republik, yakni Republik Maldives yang sebelumnya adalah pulau Maldives. Negara ini terletak di bagian utara lautan India, kira-kira $500 \mathrm{~km}$ atau 310 mil barat daya India. Penduduk yang menghuni negara ini berasal dari Srilanka, India, dan Arab. Bahasa yang mereka gunakan adalah bahasa Divehi yang berasal dari Srilanka. Secara umum penduduk negara ini memeluk agama Islam. ${ }^{6}$

Selain itu, Abdullah Saeed juga aktif dalam berbagai organisasi dan seminar internasional. Ia adalah intelektual yang sangat produktif. Penelitian-penelitiannya ia fokuskan pada negosiasi antara teks dan konteks, serta antara jihad dan interpretasi. Dia menulis untuk kalangan intelektual dan umum. Banyak karya dalam bentuk buku, artikel atau makalah seminar yang telah dipublikasikan. Berikut karya Saeed dalam bentuk buku yang terkait dengan studi al-Qur'an: 1. The Qur'an: An Introduction (Routledge, 2008); 2. Islamic Thought: An Introduction (Routledge, 2006); 3. Interpreting the Qur'an: Towards a Contemporary Approach (Routledge, 2006); 4. Contemporary Approaches to Qur'an in Indonesia, sebagai editor (Oxford University Press, 2005 . $^{7}$

Saeed juga menulis beberapa buku tentang isu kebebasan agama, politik dan Islam di Australia: 1. Freedom of Religion, Apostasy and Islam, ditulis bersama H. Saeed (Ashgate Publishing, 2004); 2. Muslim Australians: Their Beliefs, Practices and Institutions (Commonwealth Government, 2004); 3. Islam and Political Legitimacy, sebagai editor bersama S.

6 Lien Iffah Nafatu Fina, "Interpretasi Kontekstual: Studi Pemikiran Hermeneutika Al-Qur'an Abdullah Saeed," Esensia: Jurnal Ilmu-Ilmu Ushuluddin 12, no. 1 (January 22, 2011): 159-80, https://doi.org/10.14421/esensia.v12i1.707.

7 Annas Rolli Muchlisin, "Penafsiran Kontekstual: Studi Atas Konsep Hierarki Nilai Abdullah Saeed", Maghza, Vol. 1, No. 1, Januari-Juni 2016, n.d. 
Akbarzadeh (Curzon, 2003); 4. Islam in Australia (Allen \& Unwin, 2002); 5. Muslim Communities in Australia, sebagai editor besama S. Akbarzadeh (University of New South Wales Press, 2002). Selain itu ada puluhan artikel dan makalah seminar Abdullah Saeed yang bisa ditelusuri langsung dalam situs resminya. ${ }^{8}$

\section{TRANSMISI AWAL PENGETAHUAN AGAMA}

Pengetahuan agama Islam pertama kali disampaikan melalui Alquran (Firman Allah yang diterima oleh Nabi Muhammad melalui wahyu, dan ditulis dalam bentuk mushaf tidak lama setelah kematian Nabi) dan interpretasinya. Nabi Muhammad biasa menyampaikan makna ayat-ayat Alquran kepada para sahabat. Ketika terjadi permaslahan-permasalahan yang tengah dihadapi maka turun wahyu Allah sebagai jawaban atas masalah tersebut, dan disampaikan Nabi kepada para sahabatnya.

Kesulitan pertama yang dialami oleh sahabat yaitu sulit memahami beberapa istilah dan ungkapan dalam Al-Qur'an. kesulitan yang kedua, para sahabat kesulitan untuk memahami beberapa referensi sejarah dalam Alquran. Ketertarikan pada referensi tersebut, terutama pada kisah-kisah para Nabi sebelumnya (seperti Nabi Nuh, Nabi Ibrahim dan Nabi Musa) dan bangsa-bangsa di masa lalu, semakin meningkat ketika para sahabat mulai menguraikan Alquran setelah Nabi Muhammad wafat. Beberapa sahabat mendekati Yahudi dan Kristen setempat yang dikenal sebagai "orang-orang dari Kitab" (ahli al-Kitab) dan bertanya kepada mereka mengenai peristiwa dan kisah pra-Islam. Sejumlah Yahudi yang masuk Islam, seperti

8 Sheyla Nichlatus Sovia, "Interpretasi Kontekstual (Studi Pemikiran Hermeneutika Al-Qur'an Abdullah Saeed)," Dialogia: Jurnal Studi Islam Dan Sosial 13, no. 1 (December 8, 2016): 51-64, https://doi.org/10.21154/dialogia.v13i1.282.
Abdullah bin Sallam (wafat 43/663), secara aktif menyampaikan pengetahuan al-Kitab kepada para sahabat. Dalam masa ini, beberapa sahabat terlibat dalam persoalan ini dalam skala yang jauh lebih besar dengan mualaf dari ahli al-Kitab. Berkembangnya hadits-hadits tentang perkataan dan perbuatan Nabi Muhammad juga menarik minat para sahabat serta ketegangan politik dan agama serta munculnya tren-tren utama.

Tiga puluh tahun pertama setelah wafatnya Nabi Muhammad (11-41/632-661) adalah periode ketegangan sosial dan politik dalam tubuh pokitik kaum muslim. Masalah di kalangan umat Islam bukan hanya mengenai kepemimpinan politik tetapi juga mengenai apa dan siapa yang mewakili otoritas agama. beberapa muslim memilih netral dalam berpolitik. Adapun yang lain memihak kepada golongan yang berargumen tentang siapa yang benar-benar bukan muslim dan siapa yang benar-benar muslim. ${ }^{10}$

Pergolakan umat Islam terus berlanjut hingga periode Umayyah (41-132/661-750). Beberapa golongan dengan beragam orientasi teologis atau religio-politik muncul. Diantaranya adalah Kharijis (khawarij), Syiah, Qadaris (qadariyya), Mu'tazilis (mu'tazila), Jabris (jabriyya) dan Murji'is (murji'a).

\section{Khawarij}

Khawarij merupakan aliran yang pertama dari kelompok-kelompok lainnya, aliran ini muncul sebelum terbentuknya pemerintaha Umayyah pada 41/661. Mereka terbentuk setelah pertempuran Sifin di 37/657, yang membawa khalifah keempat, Ali bin Abi Talib (wafat 40/661), berperang dengan gubernur Suriah Mu'awiyah bin Abi Sufyan (wafat 60/680). ${ }^{11}$ Para Khariji meyakini bahwa dengan terlibat dalam perang melawan satu

\footnotetext{
9 Abdullah Saeed, Islamic Thought An Introduction, 6

${ }^{10}$ Ibid, 6

${ }^{11} \mathrm{~W}$. Montgomery Watt, The Majesty that Was Islam : The Islamic World, (London : Sidgwick, 1974), 661
} 
sama lain dan dengan melakukan dosa besar, umat Muslim di kedua sisi perang ini menjadi murtad atau tidak percaya. Para Khariji juga percaya bahwa setiap Muslim, terlepas dari latar belakang etnis atau status sosial, dapat menjadi pemimpin politik umat Islam hanya berdasarkan kebajikan agama mereka dan penolakan untuk berkompromi. ${ }^{12}$

Khawarij secara etimologis berasal dari bahasa Arab yaitu Kharaja yang berarti keluar, muncul, timbul, atau memberontak. ${ }^{13}$ Berkenaan dengan pengertian etismologis ini, Syahrastani menyebut orang yang memberontak imam yang sah sebagai khawarij. Berdasarkan pengertian etimologi ini pula, Khawarij berarti setiap muslim yang memiliki sikap laten ingin keluar dari kesatuan umat Islam dan tentunya menimbulkan hubungan yang tidak baik dengan ulama yang mengendepankan perdamaian.

Demi mencari ketenangan dalam menjalankan pemerintahan, Ali memindahkan pusat pemerintahannya dari Madinah ke kufah. Ia juga memecat sejumlah gubernur yang dulu diangkat Usman bin Affan, termasuk Muawiyah bin Syofyan. Pemecatan ini dilakukannya antara kain karena ia menilai bahwa terjadinya keresahan di zaman Usman sehingga Usman terbunuh adalah karena pengangkatan dan sikap para gubernur. Tindakan ini membuat keluarga Usman tidak senang dengan Ali, terutama Muawiyah. Ia tidak menerima pemberhentian atas dirinya dan menyusun kekuatan untuk menentang dan menyingkirkan Ali. ${ }^{14}$

Pertentangan antara Ali dan Muawiyah terus berlanjut dan berkembang sehingga pertentangan antara Bani Hasyim dan Bani Umayyah dengan pendukung mereka masing-

12 Ahmad Amin, Fajr al-Islam, (Cairo: Maktabat al-Nahda al-Misriyya, 1975), 258

13 Abdul Rozak, Rosihon Anwar, Ilmu Kalam, (Bandung: Pustaka Setia, 2012), 63

${ }^{14}$ Yusran Asmuni, Ilmu Taubid, (Jakarta : Citra Niaga, 1993), 102 masing. Puncak dari pertentangan itu terjadi dengan pecahnya perang Shiffin, perang antara pasukan Ali dan Muawiyah. Dengan kepandaian Amr bin al-Ash, pendukung Muawiyah, perang yang hampir dimenangkan pasukan Ali di akhiri dengan tahkim. Sebagian tentara Ali tidak menerima tahkim itu. Mereka berpendapat, orang yang mau berdamai pada saat pertempuran adalah orang yang ragu akan kebenaran perang itu, padahal hukum Allah jelas bahwa pemberontakan harus diperangi. Golongan ini yang semula mendukung Ali, menjadi berbalik membenci dan memusuhi Ali. Mereka ini kemudian diberi nama Khawarij yang berarti kaum yang keluar dan memisahkan diri dari Ali. ${ }^{15}$ Secara umum ajaran-ajaran pokok Khawarij adalah : Orang islam yang melakukan dosa besar adalah kafir, orang-orang yang terlibat dalam perang jamal (perang antara Aisyah, Thalhah dan Zubair dengan Ali) dan para pelaku tahkim termasuk yang menerima dan membenarkannya dihukum kafir, dan khalifah harus dipilih langsung oleh rakyat. $^{16}$ Ciri khusus orangorang Khawarij mempunyai pandangan yang radikal dan ekstrem, kecuali aliran al-Ibadiyah yang pendapatnya agak moderat, sebagaimana diterangkan : "Mereka adalah aliran Khawarij yang paling moderat, pendapat-pendapatnya kebanyakan benar, paling dekat pemikirannya dengan Ahlus Sunnah dan paling jauh dari pendapat-pendapat yang melampaui batas".

Adapun aliran Khawarij radikal, salah satunya ialah aliran al-Ajaridah, mereka berpendapat, antara lain $:^{17}$ tidak mengakui surat Yusuf termasuk ayat-ayat Alquran, aliran al-Ajaridah tidak menghalalkan harta bendanya kecuali pemiliknya dibunuh, dan menghalalkan

${ }^{15}$ Abu Hasan al-Asy ari, Maqalat al-Islamiyin wa al-Akhta' al Musalliin, Juz 1 (Bairut: Maktabah al Ashriyah, 1990), 207

${ }^{16}$ Yusran Asmuni, Ilmu Taubid, 105

17 Sahilun A. Nasir, Pemikiran Kalam (Theologi Islam), (Jakarta : Rajawali Pers, 2010), 138 
menikahi cucu perempuannya sendiri, dan cucu kemenakannya.

Syi'ah

Syiah, yang namanya diambil dari shi at Ali (partisan Ali), percaya bahwa dalam suksesi politik keluarga Nabi harus diberi prioritas di atas Muslim lainnya. Mereka berpendapat bahwa Ali, sepupu dan menantu Nabi, seharusnya menjadi penerus politik langsungnya. Semua kepemimpinan politik masyarakat harus tetap berada dalam keluarga Nabi. Dari posisi dasar ini, Syiah mengembangkan sistem teologis yang khas selama tiga abad pertama Islam.

Syi'ah secara bahasa berarti pengikut, pendukung, partai atau kelompok, sedangkan secara terminologis istilah ini dikaitkan dengan sebagian kaum muslim yang dalam bidang spritual dan keagamaan merujuk pada keturunan Nabi Muhammad SAW atau disebut sebagai abl al-bait. ${ }^{18}$ Menurut AthThabathaba'i, istilah Syi'ah untuk pertama kalinya ditujukan pada para pengikut Ali, pemimpin pertama abl al-bait pada masa Nabi Muhammad SAW. Para pengikut Ali yang disebut Syi'ah diantaranya adalah Abu Dzar Al-Ghifffari, Jabir ibn Abdillah, Huzaifah Ibnul Yaman, dan Salman Al-Farisi. ${ }^{19}$

Pada mulanya Syi'ah lebih berorientasi kepada aspek politik, yaitu orang-orang yang berjuang membela Ali melawan orang-orang yang memusuhi Ali. Namun, dalam perkembangan sejarahnya, Syi'ah juga menjadi salah satu mazhab dalam teologi Islam. Mereka beranggapan, yang berhak menjadi pemimpin umat Islam hanya Ali dan keturunannya. Selainnya, tidak. ${ }^{20}$ Pokok-pokok aliran Syi'ah ialah :

1. Al-Taubid

18 Abdul Rozak, Rosihon Anwar, Ilmu Kalam..., 111

${ }^{19}$ Syalabi, Ahmad, Sejarah dan Kebudayaan Islam, terj. Mukhtar Yahya dan Sanusi Latief, (Jakarta: Pustaka Al-Husna, 1992), 176

${ }^{20}$ Yusran Asmuni, Ilmu Tauhid..., 130
Kaum Syiah mengimani sepenuhnya bahwa Allah itu ada, Maha Esa, tunggal, tempat bergantung segala makhluk, tidak beranak dan tidak diperanakkan dan tidak seorangpun serupa dengan-Nya. Keyakinan seperti ini tidak berbeda dengan akidah kaum muslimim pada umumnya.

2. Al-'Adl

Kaum Syi'ah mempunyai keyakinan bahwa Allah Maha Adil. Allah tidak melakukan perbuatan zalim dan perbuatan buruk seperti berdusta dan memberikan beban yang tak dapat dipikul manusia.

3. Al-Nubunwab

Kepercayaan Syiah terhadap nabi-nabi juga tidak berbeda dengan kaum muslimin yan lain. Menurut mereka, Allah mengutus sejumlah nabi dan rasul ke muka bumi untuk membimbing umat manusia.

4. Al-Imamah

Imamah berarti kepemimpinan dalam urusan agama dan dunia sekaligus. Ia pengganti Rasul dalam memelihara syariat, melaksanakn budud (had/hukuman terhadap pelanggar hukum Allah), dan mewujudkan kebaikan dan ketentraman umat.

5. Al-Ma'ad

Ma'ad berarti tempat kembali. Yang di maksud disini ialah hari kiamat. Kaum Syi'ah percaya sepenuhnya akan adanya hari kiamat, bahwa hari kiamat itu pasti terjadi.

\section{$\underline{\text { Murizah }}$}

Murjis menentang pandangan Khariji bahwa siapa pun yang melakukan dosa besar adalah orang yang tidak beriman. ${ }^{21}$ Murji bukanlah kelompok yang berbeda, melainkan kecenderungan intelektual yang luas, yang menarik sejumlah besar umat Islam. Para Murji berpendapat bahwa kepercayaan seseorang harus dinilai bukan atas tindakan mereka tetapi atas kata-kata mereka. Hanya dengan melakukan dosa penyembahan berhala

${ }^{21}$ W. Montgomery Watt, The Majesty ..., 69 
(syirik) seorang Muslim berhenti menjadi seorang beriman.

Kata Murji'ab diambil dari kata arja'a yang berarti menunda, melambatkan dan mengemudiankan. ${ }^{22}$ Murjiah bisa berarti aliran yang mengemudiankan amal dari iman dan ada juga yang menunda persoalan dosa itu sampai hari kiamat. Bisa pula murjiah berarti suatu mazhab kalam yang mengharapkan agar dosadosa itu diampuni dan ditukar oleh Tuhan dengan kebaikan.

Ditengah pertentangan antara Ali dan Muawiyah, lahirlah Murjiah sebagai golongan yang ingin bersikap netral dan tidak mau ikut dalam kafir-mengkafirkan seperti yang dilakukan kelompok yang bertentangan itu. Bagi Murjiah, kelompok Ali dan Muawiyah masih dapat dipercaya. Oleh sebab itu, golongan ini tidak mau mengeluarkan pendapat tentang siapa yang salah atau yang benar dan menunda penyelesaiannya pada hari kiamat.

Golongan Murji'ah muncul di tengahtengah memuncaknya perdebatan mengenai pelaku dosa besar. ${ }^{23}$ Apakah pelau dosa besar masih tetap beriman atau tidak? Menurut Khawarij orang itu menjadi kafir, sedangkan menurut Mu'tazilah orang itu bukan mukmin, melainkan hanya Muslim. Hasan Basri dan sebagian Tabi'in mengatakan bahwa orang itu munafik. Alasannya mereka, perbuatan merupakan cermin dari hati, sedangkan ucapan tidak dapat dijadikan indikator bahwa seseorang telah beriman. Para ulama membagi penganut Murji'ah ke dalam dua golongan. Pertama ialah Murji'ah al-Sunnah, yaitu yang berpendapat bahwa pendosa akan disiksa sesuai dengan ukuran dosanya, dan tidak kekal di neraka. Bisa saja Allah memaafkan dan menaunginya dengan rahmat-Nya sehingga

\footnotetext{
22 Afrizal M, Ibnu Rusyd Tujub Perdebatan Utama dalam Theologi Islam, (Jakarta : Erlangga, 2006), 24

23 Imam Muhammad Abu Zahrah, Aliran Politik dan Akidah dalam islam, (Jakarta: Logos, 1996), 143
}

tidak disiksa sama sekali, dan itu merupakan karunia Allah yang diberikan-Nya kepada siapa pun yang dikehendaki-Nya (Allah memiliki karunia yang maha besar). Kelompok kedua ialah Murji'ah al-Bid'ah, yaitu mereka yang secara khusus memakai nama Murji'ah di kalangan mayoritas umat Islam. Mereka inilah yang berhak menerima ungkapan dan penilaian buruk dari semua pihak. ${ }^{24}$

Labariyah

Menurut Jabris, manusia tidak memiliki kendali atas tindakan mereka, karena semuanya sudah ditentukan oleh Tuhan. Beberapa Bani Umayyah menggunakan ide-ide agama dan agama untuk membenarkan keputusan mereka tentang masalah politik dan untuk melegitimasi pemerintahan mereka, dan mendukung pandangan Jabris dan Murji. Ini tidak mengejutkan, karena sejumlah penguasa Umayyah melakukan kejahatan keji termasuk pembunuhan orang-orang Muslim secara tidak sengaja. Menurut pandangan Khariji, para penguasa ini seharusnya digulingkan sebagai orang-orang yang tidak beriman dan penguasa yang tidak cocok dari komunitas Muslim. Namun, dalam pandangan Jabri para penguasa ini tidak dapat dicap sebagai orang yang tidak percaya karena Tuhan telah menentukan tindakan mereka dan dengan demikian legitimasi mereka tetap relatif tidak ternodai. ${ }^{25}$

Kata Jabariyyah berasal dari jabara yang berarti memaksa. ${ }^{26}$ Ali Mudhafir mengartikan jabbara dengan alzamahu fi fi'lih, berkewajiban dalam pekerjaan. Bila dilihat kedudukannya sebagai ciptaan Tuhan, orang itu tidak mempunyai wewenang apa-apa. Ia berbuat hanya mengikuti perintah Tuhan. Inilah yang disebut dengan si kap jabr (pasrah). Sebelum masuk Islam, sikap jabr telah ditemukan dalam masyarakat Arab. Suasana padang pasir membuat mereka banyak bersikap pasrah,

\footnotetext{
24 Ibid, 148

Introduction, 8

25 Abdullah Saeed, Islamic Thought An

${ }^{26}$ Afrizal M, Ibnu Rusyd.... 27
} 
tidak dapat berbuat banyak kecuali hanya menyesuaikan diri dengan kondisi itu. Mereka tidak banyak menemukan jalan untuk mengubah nasib mereka sendiri, mereka merasa lemah dan tidak mampu menhadapi kesukaran-kesukaran yang ditimbulkan oleh suasana padang pasir itu sehingga hidup mereka banyak bergantung kepada alam. Hal inilah yang membuat mereka bersikap pasrah.

Paham jabariyah ini mulai berkembang pada awal masa pemerintahan Bani Umayyah dan pada akhirnya berubah menjadi sebuah mazhab. ${ }^{27}$

Hasan al-Bashri pernah menulis sebuah risalah kepada sekelompok orang dari penduduk Bashrah yang menyiarkan paham jabariyah. Dalam risalah itu tertulis, :

"Barangsiapa tidak beriman kepada Allah serta ketentuan dan qadr-Nya berarti telah kafir. Barang siapa memikul dosa kepada Tuhannya, berarti telah kafir. Sesungguhnya kepatuhan dan kedurhakaan terhadap Allah bukan atas dasar paksaan. Allah maha pemilik apa yang mereka miliki, dan maha kuasa atas apa yang mereka kuasai. Jika mereka melakukan suatu ketaatan, Dia tidak ikut campur dalam perbuatan mereka itu". ${ }^{28}$

Sebagian ahli mengatakan bahwa mulamula penganut paham ini adalah sekelompok orang Yahudi. Mereka mengajarkannya kepada sekelompok umat Islam yang kemudian menyiarkannya. Ada pula yang mengatakan bahwa yang mula-mula menyerukan paham ini di antara umat Islam adalah Ja'd ibn Dirham yang menerimanya dari seorang Yahudi di daerah Syam. Paham yang dikembangkan berkaitan dengan pemikiran-pemikiran Jabariyah ialah :

1. Surga dan neraka akan fana, tidak ada sesuatu pun yang kekal selamanya. Kekekalan yang disebut di dalam Alquran

\footnotetext{
27 Imam Muhammad Abu Zahrah, Aliran Politik,,.. 121

${ }^{28}$ Ibid, 122
}

adalah masa yang panjang, tetapi setelah itu akan binasa, bukan kekal mutlak.

2. Iman adalah pengenalan dan kekufuran adalah ketidaktahuan.

3. Kalam Allah adalah baru, bukan qadim.

4. Allah bukan sesuatu, tidak pula bersifat mengetahui dan hidup.

5. Allah dapat dilihat pada hari kiamat.

Inti dari paham jabariyah ialah manusia tidak mempunyai kehendak dan tidak melakukan perbuatan (tetapi semuanya dari Allah). Para ulama Khalaf dan Salaf telah berusaha menentang paham ini. Begitupun dengan Ibn Abbas dan Hasan al-Bashri telah menolak dan membantah paham Jabariyah. ${ }^{29}$

\section{Qadariyah}

Qadaris percaya bahwa Tuhan tidak menentukan apa yang dilakukan manusia: manusia bebas dan dapat memilih antara yang benar dan yang salah. Ini bertentangan dengan kepentingan penguasa Umayyah. Posisi Qadari menyiratkan bahwa mungkin untuk menantang dan bahkan mengubah status quo. Pandangan radikal ini, terutama jika didukung oleh militan Khariji, yang menurutnya siapa pun yang melakukan dosa besar adalah orang yang tidak beriman, menimbulkan ancaman yang berpotensi kuat bagi elit politik Umayyah.

Qadariyah berasal dari qadara yang berarti berkuasa. ${ }^{30}$ Maksud berkuasa adalah mempunyai kekuasaan. Tuhan disebut qadir karena Dia mempunyai qudrah yang sangat besar dan dahsyat. Manusia bisa berbuat karena dalam dirinya juga terdapat qudrah. Qadariyah mencurahkan perhatian kepada perbuatan Allah dan perbuatan manusia. Tidak banyak diketahui, kapan dan bagaimana qadariah muncul di dunia Islam. Menurut qadariah, manusia berkuasa atas perbuatannya, mempunyai kebebasan dalam menentukan perjalanan hidupnya, dan mempunyai kekuatan sendiri untuk mewujudkan perbuatannya. 
Pada akhir masa pemerintahan alKbulafa al-Rasyidin dan masa pemerintahan Bani Umayyah, kaum Muslimin membincangkan masalah al-Qadha dan al-Qadr. Sebagian mereka yaitu penganut paham Jabariyyah, memahaminya secara berlebihan sehingga menafikan adanya kehendak manusia dalam melakukan perbuatannya. Sebagian lagi yang juga berlebihan, yaitu penganut paham qadariyyah, mengatakan bahwa semua perbuatan manusia adalah kehendaknya sendiri, bebas dari kehendak Allah. Di antara penganut paham ini ialah golongan Mu'tazilah, walaupun mereka lebih dikenal dengan pembahasan kalam yang lain dan salah satu masalah yang mereka bahas adalah al-qadr. ${ }^{31}$

Syaikh al-Islam negara Turki terdahulu, almarhum Syeikh Mushthafa Shabri Affandi menyebutkan bahwa kenapa dinamai qadariyyah karena dekatnya pandangan mereka dengan keyakinan sebagian penganut agama majusi. Orang majusi menisbahkan kebaikan kepada Tuhan, kejahatan kepada setan dan mengatakna bahwa kejahatan itu sesungguhnya tidak dikehendaki Tuhan. Dalam kitab Sarh alUyun, orang yang pertama kali melahirkan paham ini ialah seorang laki-laki penduduk Irak, yang mula-mula beragama Nashrani, lalu masuk Islam, kemudian murtad kembali ke agama Nashrani. ${ }^{32}$

Mu'tazilah

Mu'tazilah berasal dari kata i'tazalaya'tazilu-i'tizal-i'tizalan, yang berarti memisahkan diri atau mengasingkan diri. Kata tersebut dapat digunakan dalam setiap tindakan, seperti seseorang yang mengasingkan diri atau memisahkan diri dari kelompoknya,

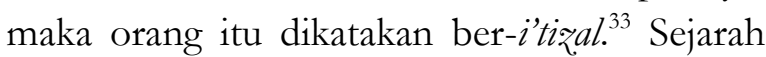
telah membuktikan bahwa lahirnya aliran ini

\footnotetext{
31 Imam Muhammad Abu Zahrah, Aliran Politik,,.. 131

32 Ibid, 133

33 Richard C. Martin (et.al), Post Mu'tazilah (Genologi Konflik Rasionalisme dan Tradisionalisme Islam), (Yogyakarta : Ircisod, 2002), 329
}

diawali dengan adanya peristiwa politik. Peristiwa tersebut adalah terjadinya pembunuhan terhadap khalifah Usman ibn Affan. Dengan terbunuhnya Usman telah menimbulkan persoalan tentang orang mukmin melakukan dosa besar. Bahkan ketika Ali mati terbunuh persoalan ini menjadi lebih santer yaitu meliputi apa hukum pelaku dosa besar? Pelaku dosa besar dalam bahasa Inggris disebut capital sinners. ${ }^{34}$

Kaum Khawarij menyatakan bahwa pelaku dosa besar adalah kafir, dalam arti keluar dari Islam atau menjadi murtad, oleh karena itu, ia harus dibunuh. Sedangkan kaum Murji'ah menyatakan bahwa pelaku dosa besar tidak kafir, imannya tidak rusak karena perbuatan tersebut tidak merusak iman, oleh sebab itu ia masih mukmin. Adapun dosa yang dilakukannya terserah kepada Allah SWT untuk mengampuninya.

Mu'tazilah menerima beberapa pandangan Qadariyah tentang kebebasan manusia. Mereka setuju dengan beberapa pandangan Khariji, meskipun mereka memodifikasi definisi 'orang beriman sejati' dan status mereka yang melakukan dosa besar. Mu'tazilis juga bertujuan melestarikan monoteisme Islam yang ketat dengan menekankan keunikan Tuhan. Sebagai bagian dari ini, mereka percaya, misalnya, bahwa Alquran (yang dianggap sebagai pidato Tuhan) 'diciptakan' oleh Allah. Bagi mereka, jika Muslim percaya bahwa Alquran adalah pidato Tuhan dan karena itu bersifat kekal dengan Allah, itu akan membahayakan tauhid yang diajarkan Alquran dan Nabi. ${ }^{35}$

Pendapat lain mengatakan, bahwa golongan mu'tazilah muncul pada masa pemerintahan Bani Umayyah, tetapi menghebohkan pemikiran keislaman pada masa pemerintahan Bani Abbas dalam masa

34 Harun Nasution, Teologi Islam Aliran-Aliran Sejarah Analisa Perbandingan, (Jakarta: Universitas Indonesia Press, 1986), cetakan ke-5, 7

35 Abdullah Saeed, Islamic Thought ..., 9 
yang cukup panjang. Para ulama berbeda pendapat tentang waktu munculnya golongan ini. Sebagian berpendapat, golongan ini mulai timbul sebagai satu kelompok dikalangan pengikut Ali. Mereka mengasingkan diri dari masalah-masalah politik dan beralih ke masalah aqidah ketika Hasan turun dari jabatan khalifah untuk digantikan oleh Mu'awiyah Ibn Abi Syofyan. Mengetahui hal ini, Abu al-Hasan al-Thara'ifi dalam bukunya Abl al-Ahwa wa al-Bida' menyatakan "Mereka menamakan diri dengan Mu'tazilah ketika Hasan ibn 'Ali membai'at Muawiyah dan menyerahkan jabatan khalifah kepadanya. Mereka mengasingkan diri dari Hasan, Mu'awiyah dan semua orang. Mereka menetap di rumah-rumah dan masjid-masjid. Mereka berkata, "Kami bergelut dengan ilmu dan ibadah". ${ }^{36}$

Pada umumnya, ulama berpendapat bahwa tokoh utama Mu'tazilah adalah Washil ibn 'Atha'. Ia adalah salah seorang peserta dalam forum ilmiah Hasan al-Bashri. Di forum ini muncul masalah yang hangat, yaitu masalah pelaku dosa besar. Washil berkata dan menentang pendapat Hasan, "Menurut saya pelaku dosa besar sama sekali bukan mu'min, bukan pula kafir, melainkan ia berada di antara dua posisi itu. Washil kemudian menghindari forum Hasan dan membentuk forum baru di masjid yang sama. Hasan mengemukakan pendapat tentang pelaku dosa besar yang mirip dan tidak bertentangan dengan pendapat mereka, karena ia berpendapat bahwa pelaku dosa besar adalah munafik, kesamaannya ialah bahwa orang munafik juga kekal dalam neraka dan tidak termasuk ke dalam kelompok orang beriman.

Kenapa namanya Mu'tazilah? Karena nama itu merupakan pecahan dari kata yang menggambarkan munculnya paham ini, menurut ulama yang mengatakan bahwa

36 Imam Muhammad Abu Zahrah, Aliran Politik,,. 149 munculnya ketika Washil mengasingkan diri dari forum Hasan. Sebagian orientalis berpendapat bahwa mereka dinamai Mu'tazilah karena mereka terdiri dari orangorang yang menjaga harga diri, sulit ekonominya dan menolak hidup bersenangsenang. Kata Mu'tazilah menunjukkan bahwa orang yang menyandang predikat itu adalah mereka yang hidup zuhud terhadap dunia. Sebenarnya tidak semua penganut paham ini seperti itu, tapi sebagiannya bertaqwa, dan ada pula yang dituduh melakukan pekerjaanpekerjaan maksiat, banyak yang baik dan ada pula yang jahat.

Adapun paham dari Mu’tazilah ialah: ${ }^{37}$

\section{Al-Taubid}

Al-Taubid (pengesahan Tuhan) merupakan paham Mu'tazilah Al-Asy'ari menggambarkan paham ini dalam bukunya yaitu Maqilat al-Islamiyyin.

2. Al-"Adl

Al-Mas'udi dalam kitabnya, Muruj alDrahab, menerangkan bahwa prinsip keadilan sesuai dengan pandangan Mu'tazilah, yaitu "Allah tidak menyukai kerusakan, dan tidak menciptakan perbuatan hamba, tetapi hambalah yang melakukan apa yang diperintahkan dan yang dilarang dengan daya yang diberikan dan diletakkan Allah kepada mereka.

3. Al-Wa'd wa al-Wa'id (Janji dan ancaman)

Mereka berkeyakinan bahwa janji berupa balasan kebaikan dan ancaman berupa siksaan tidak mustahil diturunkan. Janji Allah tentang pahala atas kebaikan akan terjadi, janji siksaan atas kejahatan juga akan terjadi, serta janji menerima taubat yang sungguh-sungguh juga terjadi. Oleh karena itu, barang siapa yang berbuat baik, akan dibalas dengan kebaikan, dan siapa yang berbuat keburukan maka akan dibalas dengan siksaan yang pedih.

\section{Al-Manzilah bain al-Manzilatain}


Uraian tentang orang yang berbuat maksiat (pendurhakaan kepada Tuhan) yang ditempatkan di antara orang yang beriman dan orang yang kafir telah dijelaskan oleh Syahrastani dalam bukunya al-Milal wa alNihal , sebagai berikut "Cara menetapkan prinsip itu ialah dengan uraian Washil ibn Atha' : Iman adalah suatu gambaran tnntang macam-macam kebaikan.

5. Al-Amr bi al-Ma'rufwa al-Naby'an al-Munkar (menyuruh berbuat baik dan melarang kemungkaran)

Sirajuddin Zar dalam Syamsuar Syam menjelaskan bahwa mereka menetapkan bahwa semua Muslim wajib melakukan upaya untuk menyiarkan dakwah Islam dan menunjuki orang yang mencampuradukkan kebenaran dan kebatilan sehingga mereka tidak dapat menghancurkan Islam. Penulis memahami bahwa lahirnya aliran Mu'tazilah merupakan sebuah kelompok aliran yang muncul dalam Islam. Aliran ini mempunyai karakteristik tersendiri. Karakteristik ini telah membawa mereka kepada cara tersendiri dalam berakidah. Metode yang mereka gunakan lebih banyak berdasarkan akal melalui perdebatan serta pola-pola filsafat Yunani. Dengan demikian dapat dikatakan bahwa aliran Mu'tazilah pada awalnya timbul dari persoalan agama, kemudian terlibat dalam persoalan politik praktis. ${ }^{38}$

Sunni

Dalam konteks teologis dan religiopolitis inilah Sunnisme berkembang antara abad pertama/ketujuh dan ketiga/kesembilan, ketika debat-debat awal memberi jalan pada sintesis semacam itu. Posisi-posisi tertentu yang diadopsi oleh semua kelompok yang disebutkan di atas disempurnakan dan dikembangkan menjadi apa yang bisa disebut pandangan 'arus

\footnotetext{
38 Syamsuar Syam, Konsep Perbuatan Manusia (Studi Terbadap Aliran-Aliran Kalam dan Ulama Kontemporer), (Padang : IAIN Press, 2008), 32
}

utama' yang diadopsi oleh mayoritas Muslim.

Penulis menilai bahwa Umat Islam yang ada saat ini terkhusus yang ada di Indonesia semuanya ialah Sunnia, karena umat muslim berpegang teguh kepada Alquran dan Ahlu Sunnah Wal Jamaah.

$\underline{\text { Sufi }}$

Sufi, atau mistisisme Islam, juga muncul pada abad kedua / kedelapan dan secara bertahap berkembang menjadi sufi di seluruh wilayah Muslim. Berbeda dengan kelompok lain, cenderung cenderung lebih akomodatif dan inklusif: Karena Suf hanya peduli pada disposisi hati, mereka bukan konformis yang mengharuskan Muslim sejati di mana pun tunduk pada mode lahiriah yang sama. Mereka mentolerir perbedaan lokal, bahkan antara Kristen dan Islam. ${ }^{39}$

Sufi merupakan orang-orang yang mengedepankan kepentingan akhirat ketimbang kepentingan duniawi. Mereka merasa bahwa akhiratlah yang penting dan utama, karena dunia ini hanyalah bersifat sesaat. Dengan demikian, kecintaan kepada Allah dan bekal untuk dikemudian hari harus dipersiapkan dengan baik, salah satunya dengan beribadah kepada-Nya.

Menurut penulis, tujuan dari Sufi ialah agar bisa dekat dengan Allah dan dapat melihat-Nya dengan cara mengosongkan pikiran yang buruk dan mengisi dengan pikiran yang baik. Salah satu tokoh sufi yang sangat dikenal akan besarnya cinta dirinya kepada Allah ialah Rabiah Al-Adawiah.

\section{PERTUMBUHAN DAN PENYEBARAN PENGETAHUAN ISLAM}

Awal pengetahuan Islam berakar pada Alquran dan tradisi Nabi. Namun, umat Islam melakukan kontak dengan berbagai peradaban sebagai akibat dari penyebaran Islam pada

39 R.K. Khuri, Freedom, Modernity, and Islam : Toward a Creative Synthesis, (Syracuse : Syracuse University Press, 1998), 224 
abad ketujuh $\mathrm{M}$, dan mewarisi bentuk-bentuk pengetahuan dari filsafat ke ilmu alam, yang mengarah pada apa yang oleh beberapa sarjana disebut sebagai 'ilmu Islam'. Muslim mewarisi pengetahuan seperti itu dari Persia, Mesir, Yunani, India, dan bahkan Cina. Pada gilirannya, umat Islam menambahkan kepada mereka dan memperkaya mereka dan mengirimkannya kepada orang lain, termasuk orang Eropa. Meskipun buku ini tidak membahas semua aspek 'ilmu pengetahuan Islam', akan bermanfaat untuk menunjukkan bagaimana beberapa pemikir Muslim mengklasifikasikan berbagai bentuk pengetahuan. Berikut ini adalah garis besar klasifikasi pengetahuan oleh filsuf Muslim alFarabi (wafat 339/950):

1. Ilmu Bahasa (dengan tujuh sub-divisi)

2. Logika (dibagi menjadi delapan bagian)

3. Ilmu Matematika (termasuk Aritmatika, Geometri, Optik, Astronomi, Musik, Bobot, dan Perangkat Cerdas)

4. Fisika atau Ilmu Pengetahuan Alam (dibagi menjadi delapan bagian)

5. Metafisika (dibagi menjadi tiga bagian)

6. Ilmu Politik, Yurisprudensi dan Teologi Dialektis. $^{40}$

Klasifikasi terkenal lainnya adalah teolog al-Ghazali (wafat 505 / 1111). Ia membagi sains menjadi 'agama 'dan' intelektual':

1. Ilmu agama: Ilmu prinsip-prinsip dasar, yaitu : Ilmu persatuan ilahi, Ilmu kenabian, Ilmu eskatologi, Ilmu sumbersumber pengetahuan agama (seperti Alquran, Sunah dan Konsensus serta ilmu-ilmu linguistik Arab).

2. Ilmu cabang atau prinsip turunan, seperti : Ilmu pengetahuan tentang kewajiban orang kepada Tuhan (upacara keagamaan dan ibadah), Ilmu tentang kewajiban orang kepada masyarakat (transaksi dan kewajiban kontraktual), Ilmu kewajiban kepada jiwa sendiri (kualitas moral).

3. Ilmu intelektual, yaitu : Matematika, Logika, Fisika atau ilmu alam, Ilmu tentang makhluk di luar alam, atau metafisika (seperti ontologi, pengetahuan tentang esensi ilahi, atribut, dan aktivitas; pengetahuan tentang zat sederhana seperti zat malaikat; pengetahuan tentang dunia halus; ilmu ramalan). ${ }^{41}$

Berbagai disiplin ilmu yang menyertai munculnya aliran pemikiran yang berbeda dalam studi Alquran dan hadis, hukum, teologi, filsafat, sains dan linguistik dan sastra Arab melihat perkembangan lembaga-lembaga pendidikan untuk menyebarluaskan pengajaran dan penelitian. Pada abad kelima / kesebelas, madrasah (seminari, perguruan tinggi, lembaga pendidikan Islam) muncul sebagai lembaga pembelajaran Islam. Para cendekiawan agama (ulama) menjadi pemancar pengetahuan Islam formal, dan membentuk elite internasional di semua bagian dunia Muslim. Ulama melihat transmisi pengetahuan sebagai tugas utama mereka, mengingat bahaya yang melekat dalam perubahan atau hilangnya ajaran otentik dengan berlalunya waktu. Semakin jauh setiap generasi bergerak dari zaman Nabi, semakin besar kemungkinan kehilangan kebenaran. Tugas utama ulama adalah untuk melestarikan, mentransmisikan, dan membela hukum agama syariah, serta memberikan keputusan hukum dan penilaian kepada masyarakat. Mereka juga melakukan berbagai fungsi lainnya, seperti mengelola masjid, sekolah dan panti asuhan, dan
${ }^{40}$ O. Bakar, Classification of Knowledge in Islam, (Cambridge : Islamic Texts Society, 1998), 121
${ }^{41}$ Ibid, 207 
melayani sebagai diplomat dan abdi dalem. $^{42}$

Selama abad ke-5/ke-11 dan ke-6/ke12, madrasah didirikan di Irak dan Suriah. Pada akhir abad keenam / kedua belas, setidaknya tiga puluh madrasah ada di Damaskus dan Kairo. Seiring berjalannya waktu, jaringan madrasah semacam itu menyebar ke seluruh penjuru dunia Muslim. Al-Azhar, seminari paling terkenal, didirikan di Kairo pada tahun 361/972 oleh Fatimiyah (297-567/909-1171), sebuah dinasti Ismaili Syiah Afrika Utara. Kemudian menjadi lembaga Sunni, dan seminari Islam tradisional terbesar di dunia Sunni. ${ }^{43}$

Di madrasah maupun di lingkungan studi lain, para cendekiawan mengajar mata pelajaran hukum dan teologis, selain kedokteran, sastra, matematika, ilmu alam, dan filsafat. $^{44}$ Di beberapa madrasah, bidang kontroversial tertentu seperti teologi, logika, dan filsafat dihindari tetapi diterima pada orang lain. Pertumbuhan dan perkembangan sistem madrasah berlanjut dan mencapai periode terbesarnya selama kekaisaran Ottoman. Menurut Rahman: Dari sudut pandang organisasi, sistem madrasah mencapai titik tertinggi di Kekaisaran Ottoman di mana madrasah dilembagakan, diberkahi, dan dipelihara secara sistematis dengan keterampilan administrasi yang luar biasa dan efisiensi. Para ulama diorganisasi dalam hierarki dan hampir menjadi kasta dalam masyarakat Ottoman. Kursi belajar tradisional ini masih berfungsi di seluruh dunia Muslim di luar Turki. ${ }^{45}$

${ }^{42}$ F. Robinson, The Cambridge Illustrated History of the Islamic World, (New York: Cambridge University Press, 1996), 219

${ }^{43}$ F. Rahman, Islam, (Chicago: University of Chicao Press, 1979), 184

${ }^{44}$ M. Chamberlain, Knowledge and Social Practice in Medieval Damascus, (Cambridge : Cambridge University Press, 1994), 83

${ }^{45}$ F. Rahman, Islam, 184
Di madrasah, teks umum sering digunakan lintas daerah dan menjadi kanon bagi sekolah hukum. Sebagai contoh, para ulama di Timbuktu (di zaman modern Mali) menggunakan buku-buku yang sama dengan buku-buku mereka di Maroko dan Mesir; keterbukaan terhadap ilmu-ilmu rasional di pihak sebagian Muslim Sunni dan Syiah juga menyebabkan kesamaan teks di antara para ulama mereka. ${ }^{46}$

Ulama menggunakan sistem sertifikasi yang disebut ijaza (lisensi). Secara tradisional, lisensi diberikan oleh seorang sarjana individu (yang bertentangan dengan lisensi yang diberikan oleh universitas) yang memungkinkan siswanya untuk meneruskan pengetahuan yang diterima dari sarjana itu. ${ }^{47}$ Ada beberapa jenis ijazas, yang seringkali verbal dari pada tertulis. 'Apa yang diberikan adalah lambang ikatan kepada seorang syaikh (guru) seperti sertifikasi dengan nilai tetap dalam hubungan sosial. ${ }^{48}$

Sementara para ulama berkobar di kota-kota dan wilayah kekuasaan negara, Suf mencapai semua bagian dunia Muslim, khususnya daerah-daerah terpencil di mana kekerabatan dan organisasi kesukuan sangat penting. Dari abad ketiga/ kesembilan, para murid berkumpul di sekitar Sufi Syaikh tertentu untuk mengikuti 'jalan' mereka (tariqa)metode mereka untuk melakukan perjalanan menuju pengetahuan pengalaman langsung tentang Tuhan, kadang-kadang berkumpul di Rumah Sakit. Ritual utama dari tarekat adalah zikir syekh (bentuk pengabdiannya yang khusus untuk mengingat Tuhan). ${ }^{49}$

Para murid Sufi Syaikh merupakan pusat transmisi pengetahuan mistik dan menjadi bagian dari rantai transmisi spiritual syaikh (silsila). Setelah inisiasi mereka, para

\footnotetext{
${ }^{46}$ F. Robinson, The Cambridge ..., 230

47 M. Chamberlain, Knowledge and Social Practice in Medieval Damascus, 88

${ }^{48}$ Ibid, 89

${ }^{49}$ Abdullah Saeed, Islamic Thought..., 12
} 
murid bersumpah setia, menerima jubah khusus, dan diajari doa perlindungan khusus. Ketika mereka menyelesaikan pelatihan mereka, mereka menerima sertifikat yang menunjukkan rantai transmisi pengetahuan spiritual, dari Nabi ke syekh khusus mereka. Dari sekitar abad ketujuh/ketigabelas, kelompok-kelompok sufi mulai membangun tatanan tertentu, yang berbeda dalam ritual dan praktik mereka untuk mengingat Tuhan. Perintah ini sangat penting dalam mentransmisikan pengetahuan mistis ke seluruh dunia Muslim. Toleransi dan fleksibilitas yang besar dari para Sufi telah membantu mereka membangun jembatan antara Islam dan tradisi keagamaan lainnya. Juga, Suf memainkan peran penting dalam menyebarkan Islam ke daerah-daerah terpencil. Pembentukan Islam yang kuat di Asia Tengah, Sind dan Bengal adalah karena para Sufi, yang juga melakukan perjalanan ke Afrika Utara, Anatolia, dan Balkan. ${ }^{50}$

\section{ULAMA DI ZAMAN MODERN}

Selama periode pra-modern (sebelum pertengahan abad ke-19 M), status sosial dan posisi ulama, sebagai pemancar pengetahuan agama, didasarkan pada berbagai peran mereka sebagai cendekiawan, hakim dan ahli hukum dan fungsi kunci lainnya di masyarakat. Sebagai administrator sumbangan amal, mereka sering kali memiliki kemandirian ekonomi yang substansial. Ulama mengendalikan pelatihan siswa, mendasarkan ini pada model di mana disiplin agama diprioritaskan. Pengaruh agama dalam semua aspek kehidupan dalam masyarakat dengan demikian menegaskan peran sosial para ulama. Sebaliknya, pada periode modern, negara bangsa telah mengambil alih banyak fungsi utama yang sebelumnya menjadi hak ulama, seringkali membatasi kekuasaan mereka dalam proses tersebut, dengan berbagai tingkat keberhasilan. $^{51}$

Bagian dari peminggiran para ulama ini adalah hasil karya mereka sendiri. Saat ini, kurikulum pendidikan untuk disiplin ilmu Islam di seminari-seminari agama (dan semakin banyak di 'universitas' Islam) dalam banyak kasus tampaknya tidak mempersiapkan para ulama untuk berurusan secara efektif dengan modernitas, apalagi kebutuhan pendidikan masyarakat modern. Studi mereka sering dianggap ketinggalan jaman. Akibatnya, bagi banyak Muslim derajat yang mereka berunding menikmati prestise kecil. Mereka yang mendaftar dalam studi Islam di masyarakat Muslim sering dipandang sebagai orang tanpa akses ke, atau kemampuan untuk melakukan, disiplin ilmu yang lebih 'mengesankan', seperti kedokteran, teknik dan ilmu pengetahuan. Mereka yang melakukan studi agama mungkin tidak memiliki kesempatan untuk pergi ke sekolah di mana mereka dapat belajar disiplin ilmu modern. Satu-satunya bentuk pendidikan mereka mungkin adalah madrasah tradisional, di mana hanya pendidikan 'agama' yang tersedia. Siswa yang kurang beruntung seperti itu mengakses pendidikan gratis yang tidak memadai di madrasah tradisional yang sering berpindah ke lembaga terpinggirkan lainnya, seminari keagamaan. Ini mempersiapkan mereka untuk menjadi fungsionaris agama yang memimpin sholat di masjid dan mengajar kelas-kelas Alquran. Yang beruntung dapat menemukan pekerjaan di birokrasi departemen urusan agama (untuk menjadi bagian dari 'ulama resmi'). Terlepas dari prospek karir, banyak dari ulama ini terlihat tidak siap untuk menghadapi masalah kehidupan modern yang lebih kompleks. ${ }^{52}$

50 R. S. Humphreys et al., Tarika', in P. J. Bearman et al. (eds), Encyclopaedia of Islam Online, 12 vols, (Leiden: Brill, 2004, 17 June 2005 http://www.encislam.brill.nl.

${ }^{51}$ Abdullah Saeed, Islamic Thought ..., 13
52 Ibid. 
Di negara-negara modern di mana hukum Islam diterapkan, seperti Saudi Arabia dan Iran, ulama 'resmi' menikmati peran yang relatif penting. Namun, di negara-negara di mana sistem hukum telah disekularisasi atau banyak dimodifikasi, peran itu terbatas dan kepentingannya minimal. Peran utama yang diberikan kepada ulama dalam sistem hukum sebagian besar negara Muslim modern adalah mengelola hukum keluarga, yang masih ditegakkan (setidaknya sebagian) di negaranegara tersebut. Hal-hal seperti pernikahan, perceraian, warisan dan dalam beberapa kasus, hak asuh anak termasuk dalam ruang lingkup hukum keluarga. Beberapa negara Muslim, misalnya Malaysia, telah mengadopsi sistem pengadilan syariah yang yurisdiksinya secara tegas didefinisikan sebagai wilayah hukum keluarga. Selain itu, ulama juga mengelola apa yang disebut 'urusan Islam'. ${ }^{53}$

\section{KESIMPULAN}

Berdasarkan uraian diatas, dapat dipahami bahwa Abdullah Saeed menjelaskan perkembangan dan hadirnya ilmu pengetahuan yang memberikan pengaruh kepada masyarakat. Selain itu, berbagai macam persoalan muncul terkait dengan terbagibaginya sekte-sekte yang terjadi pada masyarakat pada saat itu. Abdullah Saeed mencoba mengklasifikasi serta menjelaskan secara rinci dari awal kehidupan Rasulullah sampai munculnya aliran-aliran yang saling mengedepankan doktrinnya masing-masing. Berbagai pertentangan dan berbeda pendapat pada masing-masing aliran seakan telah menjadi sebuah hal yang menarik, ini dikarenakan mereka sama-sama memiliki kebenaran tersendiri. Terbentuknya berbagai macam aliran dan sekte telah diuraikan oleh Abdullah Saeed dengan cukup jelas, sehingga memberikan gambaran kepada pembaca bahwa Islam berjalan dengan berbagai pemikiran sesuai dengan doktrin yang dianggap benar. 


\section{DAFTAR KEPUSTAKAAN}

Abu Zahrah, Imam Muhammad, Aliran Politik dan Akidah dalam islam, Jakarta : Logos, 1996.

Ahmad, Syalabi, Sejarah dan Kebudayaan Islam, terj. Mukhtar Yahya dan Sanusi Latief, Jakarta: Pustaka Al-Husna, 1992.

Annas Rolli Muchlisin, "Penafsiran Kontekstual: Studi Atas Konsep Hierarki Nilai Abdullah Saeed", Maghza, Vol. 1, No. 1, Januari-Juni 2016, n.d.

Amin, Ahmad, Fajr al-Islam, Cairo: Maktabat al-Nahda al-Misriyya, 1975.

Asmuni, Yusran, Ilmu Taubid, Jakarta: Citra Niaga, 1993.

Al-Asy'ari, Abu Hasan, Maqalat al-Islamiyin wa al-Akhta' al Musalliin, Juz 1, Beirut: Maktabah al Ashriyah, 1990.

Achmad Zaini, "Model Interpretasi Al-Quran Abdullah Saeed," Islamica: Jurnal Studi Keislaman, 6, no. 1 (September 1, 2011): 25-36, https://doi.org/10.15642/islamica.2011.6.1.25-36.

Afrizal M, Ibnu Rusyd Tujuh Perdebatan Utama dalam Theologi Islam, Jakarta: Erlangga, 2006.

Bakar, O., Classification of Knowledge in Islam, Cambridge: Islamic Texts Society, 1998.

Chamberlain, M., Knowledge, and Social Practice in Medieval Damascus, Cambridge: Cambridge University Press, 1994.

Hasan, M. Iqbal, Pokok-Pokok Materi Metodologi Penelitian dan Aplikasinya, Jakarta: Ghalia Indonesia, 2002.

Khuri, R.K., Freedom, Modernity, and Islam: Toward a Creative Synthesis, Syracuse: Syracuse University Press, 1998.

Lien Iffah Nafatu Fina, "Interpretasi Kontekstual: Studi Pemikiran Hermeneutika Al-Qur'an Abdullah Saeed," Esensia: Jurnal Ilmu-Ilmu Usbuluddin 12, no. 1 (January 22, 2011): 159-80, https://doi.org/10.14421/esensia.v12i1.707.

Nasution, Harun, Teologi Islam Aliran-Aliran Sejarah Analisa Perbandingan, Jakarta: Universitas Indonesia Press, 1986.

Nasir, Sahilun A., Pemikiran Kalam (Theologi Islam), Jakarta: Rajawali Pers, 2010

Rozak Abdul, Anwar Rosihon, Imu Kalam, Bandung: Pustaka Setia, 2012

Richard C. Martin (et.al), Post Mu'tarilah, Genologi Konflik Rasionalisme dan Tradisionalisme Islam, Yogyakarta: Ircisod, 2002.

Robinson, The Cambridge Illustrated History of the Islamic World, New York: Cambridge University Press, 1996

Rahman, F., Islam, Chicago: University of Chicago Press, 1979.

R. S. Humphreys et al., Tarika', in P. J. Bearman et al. (eds), Encyclopaedia of Islam Online, 12 vols, (Leiden: Brill, 2004, 17 June 2005 http://www.encislam.brill.nl.

Saeed, Abdullah, "Transmission Of Religious Knowledge And Islamic Thought," Dalam: Abdullah Saeed, Islamic Thought; An Introduction, London And New York: Routledge, 2006

Syam, Syamsuar, Konsep Perbuatan Manusia (Studi Terbadap Aliran-Aliran Kalam dan Ulama Kontemporer), (Padang: IAIN Press, 2008)

Sahilun A. Nasir, Pemikiran Kalam (Theologi Islam), Jakarta : Rajawali Pers, 2010

Sheyla Nichlatus Sovia, "Interpretasi Kontekstual (Studi Pemikiran Hermeneutika Al-Qur'an Abdullah Saeed)," Dialogia: Jurnal Studi Islam Dan Sosial 13, no. 1 (December 8, 2016): 5164, https://doi.org/10.21154/dialogia.v13i1.282.

Watt, W. Montgomery, The Majesty that W as Islam : The Islamic World, London : Sidgwick, 1974

Yusran Asmuni, Ilmu Taubid, Jakarta : Citra Niaga, 1993 